\title{
Ethnobotany of the Kiluhikturmiut Inuinnait of Kugluktuk, Nunavut, Canada
}

\author{
Jonathan Duffy Davis ${ }^{1}$, Sandra Anne Banack ${ }^{2}$ \\ Author address: ${ }^{1}$ Fullerton Arboretum, California State University, Fullerton, CA 92831, ${ }^{2}$ Institute for Ethnomedicine, P.O. \\ Box 3464, Jackson, WY 83001
}

Received: September 24, 2012

Volume: 3:78-90

Published: December 29, 2012

(C) 2012 Society of Ethnobiology

Abstract: The disparity in floral diversity between tropical and arctic regions is reflected in a paucity of ethnobotanical research among arctic cultures. The Kiluhikturmiut Inuinnait are an Inuit subpopulation who inhabit the Kitikmeot Region of the Territory of Nunavut in Canada's Arctic. We conducted an ethnobotanical survey in the Inuinnait hamlet of Kugluktuk to document the traditional uses of plants as food, materials, and medicine. Data were gathered through unstructured interviews, participant observation, purposive sampling, and voucher-specimen collection of all plants used. Uses were documented for 23 plant species/types contained in 14 families. Nine species/types were eaten, six species/types were used as materials, and 12 species were used for medicine. Villagers shared common knowledge of plants used for food and materials; however, knowledge of medicinal plants was restricted to a single healer. We argue that specialized knowledge such as the use of medicinal plants is important to document especially when the number individuals using this knowledge is dwindling.

Abstract: Pitquhiitigut piruqhimayut qauyihaivlutik qanuq inuit atuqtauvagait atungauyanik niqiuvlutik, hanayauvagaillu, uumingalu havautitirniillu. Pitquhiit piruqhimayut ihivgiuqtauttianngittuni Ukiuqtartumi avatingnit. Kiluhikturmiut Inuinnait huli anguniayuktuuvlutik atuqpagait ublumi. Atuqtauttiangittuni haffuminga Ukiuqtartup pitquhiit piruqhimayut uumingalu huli atuqattaqhutik nunamiunnit taimaa pitquhiita arlingnaqhivakhunilu haffumingat pitquhiitigut piruqhimayunit qauyiharnirnit. Hamna atuqtauyumayunut ihivgiuqhiyainnit nalunaitkuhiutauvluni qanurmi atuqtauvagait atungauyait ilitquhiitigut niriyauvagainullu, pitquhiitigut, havautiturnigullu Kiluhikturmiunnut Inuinnait. Hamna pitquhiitigut piruqhimayut naunaighiniq aqtauvakhutik Kiluhikturmiunut Inuinnait pivalliahimavluni Qurluqturmi, Nunavunmi (67047.881' Kangangnaa; 1150 13.845' Uataa). Nalunaiqhiyut titiqqatigut kativagait unipkaaliuqhutik tautukpakhugillu ilauqatauyunut. Atuqtauvlutik titiraqhimayait 23 nik uumayuit aadjikiingningit/qanurittunik atungauyainnit. Arvinilik pingahuanik niriyauhimavlutik, arvinilik atauhirmik aadjikiingningit/qanurittunik atuqtauvagaillu pitquhiitigut mikhaanut, uvvalu tualunik uumayuit aadjikiingningit atuqtauvagait havautikhainnit.

Key words: ethnobiology, Coronation Gulf , Arctic, specialized knowledge

Introduction

The Inuit are aboriginal people indigenous to arctic regions. Contemporary Inuit communities are dispersed from Siberia east to Greenland. Ancestors of the Inuit are believed to have migrated across the Bering Strait from northeast Asia onto North America approximately 4,500 years ago. Archaeological evidence indicates that populations radiated across the continent, reaching Greenland within 500 years (Helgason et al. 2006).

Traditionally, the Inuit migrated across ice and tundra to exploit seasonally available prey populations. In winter, the frozen ocean provided access to seals and other marine mammals that were hunted for their ample supplies of fat to be used for food and fuel, and waterproof skins for the construction of clothing. Families lived in shelters made from blocks of snow and traveled by dogsled (Jenness 1916; Stefánsson 1913). When the ice receded in summer, many groups turned inland to hunt caribou on the tundra, traveling on foot and sheltering in tents of animal hide (Stefánsson 1913).

The Inuinnait

The Inuinnait are a subpopulation of Canadian Inuit who inhabit the Kitikmeot region in Nunavut, Canada. The relative isolation and inaccessibility of the central Canadian Arctic protected the Inuinnait from the contact with Europeans experienced much earlier by Inuit groups closer to the Atlantic and Pacific Oceans. Prior to the early twentieth-century, contact with non-indigenous peoples was limited to 
brief and sporadic encounters with explorers and Royal Navy sailors (Condon 1996). After spending seven months with a group of Inuinnait on Victoria Island, Jenness (1916) reported the sustained use of stone-age technology and regarded the Inuinnait as the only remaining Inuit group still living a traditional lifestyle. The sustained presence of European traders in the Coronation Gulf region began at the beginning of the twentieth century (Condon 1996).

The fur-trade influenced Inuinnait culture and had a long-lasting impact on hunting practices, economy, and migration patterns: the arctic fox was hunted for its fur which was traded for novel goods such as rifles, tobacco, sugar, flour, and tea. This new economy spurred settlements around trading posts (Condon 1996). The first two trading posts were constructed in Coronation Gulf region in the summer of 1916 . By $196372 \%$ of the Inuinnait population lived in the two main settlements of Coppermine and Holman (Usher 1965).

Inuinnait life has changed considerably since the early twentieth century. The Inuinnait now live in modular homes. Travel is often accomplished through all-terrain vehicles and snowmobiles. Kugluktuk has a health clinic, a school that provides elementary and secondary education, several churches, and offices of the municipal and territorial government. Food and other supplies arrive regularly by plane and once or twice each summer by ocean freighter. These supplemental freight charges greatly inflate the cost of goods in Arctic communities. The exorbitant cost of market foods is offset by subsistence hunting, a culturally salient practice that continues today. Kuhnlein et al. (2004) estimated that 28\% of the calories in the average Inuit diet was still derived from wild-harvested foods. Caribou (Rangifer tarandus C.H. Smith Cervidae) and arctic char (Salvelinus alpinus L. Salmonidae) remain integral to the Inuinnait culture and livelihood. Both are actively sought and relished.

Carl Linnaeus pioneered ethnobotanical methods in 1732 while living among the Sami of Lapland. Since this notable beginning, ethnobotanical research has remained relatively uncommon among arctic cultures. The objective of this study was to document the traditional and contemporary uses for plants among the Kiluhikturmiut Inuinnait of Kugluktuk, Nunavut, Canada. It was predicted that even within the depauperate flora of the Coronation Gulf region of the central Canadian Arctic, the Kiluhikturmiut
Inuinnait have identified and retained knowledge of useful and biologically active plants for food, materials, and the treatment of disease.

\section{Methods}

Kugluktuk began as the Inuinnait settlement of Coppermine. Today it is a hamlet of approximately 1,300 people situated on the southwestern shore of the Coronation Gulf in the Kitikmeot Region of Nunavut $\left(67^{\circ} 49.3^{\prime} \mathrm{N} ; 115^{\circ} 04.8^{\prime} \mathrm{W}\right)$. Field research was conducted in June and July of 2006 while living in Kugluktuk.

Data were gathered through daily participant observation and unstructured ethnographic interviews. Opportunities for participant observation included hunting and fishing trips, walks around the periphery of town, and other excursions. Purposive sampling methods were used as a tool to select community participants (Tongco 2007). Interviews were conducted according to guidelines presented by Spradley (1979). Five male traditional hunters, four community elders (female $=3$; male $=1$ ), and a single female traditional healer were interviewed in depth. These individuals were chosen based on recommendations of community leaders, active hunting and gathering during the period of study, ability to identify plants in the field, and availability. A hunter was considered to be someone who remained actively engaged in hunting. An elder was an older person who had grown up on the land and experienced a reasonably traditional life; the current Inuinnait settlements did not exist during the childhood of these elders. Only one traditional healer was identified by community members as residing within Kugluktuk during the period of fieldwork.

A local-government native speaking interpreter was contracted for interviews with two of the community elders. Other participants were bilingual or spoke English as their primary language. No material compensation was provided to study participants. Informed consent was obtained from each participant. Documentation of traditional knowledge was approved by the Nunavut Research Institute. Interview methods were approved by California State University, Fullerton IRB.

Each plant species mentioned during interviews was collected, identified using Porsild and Cody (1980) by Davis, and deposited at four herbaria (California State University Fullerton (MACF), Gray Herbarium at Harvard (GH), University of Guelph $(\mathrm{OAC})$, and the Canadian Museum of Nature (CAN). 
Table 1. Contemporary Use of Plants by the Kiluhikturmiut Inuinnait

\begin{tabular}{|c|c|c|c|}
\hline \multicolumn{4}{|c|}{ Plants used by the Kiluhikturmiut Inuinnait for food. } \\
\hline Name & Family & Uses & $\begin{array}{l}\text { Mentions } \\
(n=10)\end{array}$ \\
\hline $\begin{array}{l}\text { Arctostaphylos spp. } \\
\text { (kablaq) }\end{array}$ & Ericaceae & leaves, infusion & 2 \\
\hline $\begin{array}{l}\text { Empetrum nigrum } \\
\text { (paun'ngaq) }\end{array}$ & Empetraceae & raw fruit, mixed with fat & 7 \\
\hline $\begin{array}{l}\text { Hedysarum alpinum } \\
\text { (mahuk) }\end{array}$ & Fabaceae & raw root, boiled & 8 \\
\hline $\begin{array}{l}\text { Oxyria digyna } \\
\text { (qunguliit) }\end{array}$ & Polygonaceae & raw leaves and flowers, prepared in a concoction & $9 *$ \\
\hline Pedicularis capitata & Scrophulariaceae & raw nectar & $1^{*}$ \\
\hline $\begin{array}{l}\text { Rubus chamaemorus } \\
\text { (aqpik) }\end{array}$ & Rosaceae & raw fruit, mixed with fat & $7^{*}$ \\
\hline $\begin{array}{l}\text { Vaccinium uliginosum } \\
\text { (kiguangirnaq) }\end{array}$ & Ericaceae & raw fruit, mixed with fat & 7 \\
\hline $\begin{array}{l}\text { Vaccinium vitis-idaea } \\
\text { (kingmignaq) }\end{array}$ & Ericaceae & raw fruit, mixed with fat & $7^{*}$ \\
\hline Caribou stomach contents & various & raw & 1 \\
\hline \multicolumn{4}{|c|}{ Plants used by the Kiluhikturmiut Inuinnait for materials } \\
\hline Name & Family & Uses & $\begin{array}{c}\text { Mentions } \\
(n=10)\end{array}$ \\
\hline Arctostaphylos spp. & Ericaceae & tobacco substitute & 1 \\
\hline Cassiope tetragona & Ericaceae & tinder, fuel, insect repellent & 4 \\
\hline \multirow{2}{*}{$\begin{array}{l}\text { Eriophorum scheuchzeri } \\
\text { (kanguujaq) }\end{array}$} & Cyperaceae & wick for seal-oil lamp & 9 \\
\hline & & soot for tattoos & 4 \\
\hline \multirow[t]{3}{*}{ Sphagnum spp. } & Sphagnaceae & adsorbent: bandages, diapers, menstrual pads & 5 \\
\hline & & insulation & 4 \\
\hline & & sled-runners & 9 \\
\hline Driftwood & various & construction material, fuel & 6 \\
\hline Sod & various & sod-house construction & 2 \\
\hline
\end{tabular}




\begin{tabular}{|c|c|c|c|c|}
\hline \multicolumn{5}{|c|}{ Plants used today as medicine by Kiluhikturmiut Inuinnait Healer Pauline Plamondon } \\
\hline Species & Family & Uses & Parts used & Preparation \\
\hline Achillea nigrescens & Asteraceae & reproductive problems & whole & tea, incense, bath \\
\hline Arctostaphylos spp. & Ericaceae & urinary tract infections & & tea, oil infusion \\
\hline Betula glandulosa & Betulaceae & $\begin{array}{l}\text { frostbite preventative, } \\
\text { catalyst }\end{array}$ & leaf buds & oil infusion \\
\hline Castilleja elegans & Scrophulariaceae & contradictory thoughts & & tea \\
\hline Epilobium latifolium & Onagraceae & fetal alcohol syndrome & whole & concoction \\
\hline Equisetum arvense & Equisetaceae & urinary tract infection & whole & tea, maceration \\
\hline Ledum decumbens & Ericaceae & gingivitis & leaves & tea \\
\hline Oxyria digyna & Polygonaceae & chest congestion & whole & poultice \\
\hline Potentilla fructicosa & Rosaceae & sore esophagus, heart problems & leaves, petals & tea \\
\hline Salix spp.\# & Salicaceae & pain, headache, toothache & inner bark & chewed \\
\hline Silene spp. & Caryophyllaceae & anxiety & & \\
\hline
\end{tabular}

*Uses were observed in the community in addition to reports in the interview process.

\#The use of Salix spp. for pain was mentioned by five additional participants.

\section{Results}

Plants used as Food

Eight species from six families, and one plant-derived substance were reported as part of the traditional Kiluhikturmiut Inuinnait diet (Table 1). Oxyria digyna (L.) Hill Polygonaceae was the most commonly reported and recognized plant among all species recorded in the present study. Its pleasant tart flavor was commonly likened to candy and described with much relish. The entire shoot is usually consumed raw, but is also simmered in water to create an infused beverage. O. digyna is also wild gathered today along with the fruit of four other species. These contemporary wild-gathered foods are largely gathered opportunistically and eaten out-of-hand. The exception to this would be during the much celebrated berrypicking season of late summer, when families are seen gathering fruit together. While O. digyna and these other four fruits were nearly universally familiar, other edible species were known only by older adults and community elders.

\section{Plants used as Materials}

Community participants in this study identified six types of plants from three families as traditional raw materials (Table 1). Plant material seemed to be favored in situations where animal-derived materials would have proven inferior. An example of such an application was the use of Eriophorum scheuchzeri Hoppe Cyperaceae as a wick in seal-oil lamps. The cottony bristles of the perianth were gathered in autumn and stored for year-round use. This material would be rolled between the fingers and placed along a raised ledge in stone lamps (qulliq) that held rendered seal or, less commonly, caribou fat. The burning of the qulliq produced heat, light, and a means to cook meat. E. scheuchzeri facilitated the combustion of relatively abundant animal fats in a region where energy-dense, plant-based fuels were scarce. Interestingly, pots suspended over a qulliq would accumulate a layer of black soot that would be gathered and used as ink for tattoos. A thread of caribou sinew would be coated in soot and pulled through the skin of the face with a copper needle to create a dashed pattern. Women were traditionally the recipients of such tattoos and in this community is considered to denote status and accumulation of knowledge. One of the elders considered it an initiation to womanhood. 


\section{Plants used as Medicine}

The use of traditional plant-based medicines is currently limited within the community of Kugluktuk to a single healer residing in the village during the period of this study. Community members indicated that they visited this healer in addition to seeking help at a Western-based medical clinic. Eleven plant species representing ten families were identified as useful in the treatment of injury and disease (Table 1). The two oldest elders that we interviewed had spent the majority of their life in the traditional manner before permanent settlements were established. Both reported that they remember using plants for medicine since their early childhood. Although they had been treated for medicinal problems using plants, they had limited specific knowledge of these plants or treatments.

The plant-based medicine of the Kiluhikturmiut Inuinnait appears to be dynamic, with novel remedies created to address modern afflictions such as fetal alcohol syndrome: whole Epilobium latifolium L. Onagraceae plants are cooked in diluted store-bought honey until the mixture regains the viscosity of honey. A teaspoon consumed each day was reported to calm and improve mental focus.

Knowledge of medicinal plants and their preparation was transmitted orally between generations and was proprietary to initiated healers; this remains the case today. The one remaining healer in Kugluktuk indicated that normally a healer would provide medical care to four or five extended families, traveling among groups as needed. Given the lack of traditional healers in Kugluktuk today, Pauline, treats anyone who has a need and is interested in her help. She was taught to manufacture medicines by her grandmother and is actively trying to keep the knowledge alive by treating as many people as she can, and by teaching it to an apprentice. While Pauline generally prefers fresh plants, seasonal gathering, drying, and storing in stone caches of medicinally important species is necessary to insure a year-round supply. The Kiluhikturmiut Inuinnait healers exploit plants to treat and prevent a variety of conditions including infection, pain and inflammation, chest congestion, heart problems, and mental afflictions. Medicines usually included a single species. Preparation methods were highly varied, with water extracts and seal oil infusions being most common. Seal oil infusions were considered to be the best carrier of active plant constituents and were created by heating the oil and plant material. The strength of the medicine was reported to increase with oil temperature and heating duration.

\section{Discussion}

Through their ingenuity and fortitude the Inuit and their ancestors have inhabited the harsh arctic environment for millennia. Many plant species were identified as potential resources. Despite the penetration of Western practices and associated acculturation, the Kiluhikturmiut Inuinnait retain uses for the flora of the central Canadian Arctic, exploiting at least 23 species from 14 plant families, as documented in this study. While this number may appear scant in relation to the diversity of plants used by cultures in temperate or tropical environments, the number should be considered in the context of regional floristic diversity. Estimates of floristic diversity are not available for the Kugluktuk area; however, nearby Victoria Island has been estimated to contain 207 species of vascular plants (Bliss 1971). The Kiluhikturmiut Inuinnait thus retain knowledge of uses for approximately $10 \%$ of the regional flora.

Several of the Kiluhikturmiut Inuinnait food plants reported here have been noted by other authors working in arctic regions. Kuhnlein and colleagues have made several notable contributions to the study of the traditional Inuit diet (Kuhnlein and Soueida 1992; Kuhnlein et al. 2002; Kuhnlein et al. 2004). Oxyria digyna was a traditional food of the Baffin Island Inuit (Kuhnlein and Soueida 1992) and was one of the most important food plants of the Eskimo of the north Bering Sea and Arctic regions of Alaska (Anderson 1939). Hedysarum spp. Fabaceae were also used by the Eskimo of the North Bering Strait and Arctic Alaska (Anderson 1939). H. obscurum L. and $H$. alpinum L. roots were consumed by the Chukchi (Porsild 1953). The fruits gathered by the Kiluhikturmiut Inuinnait are widely used among arctic cultures (Anderson 1939; Dritsas 1986; Griffin 2001; Porsild 1953). Kuhnlein et al. (2002) report the use of Rubus chamaemoreus L. Rosaceae, Empetrum nigrum L. Ericaceae, Vaccinium uliginosum L. Ericaceae and $V$. vitis-idaea L. Ericaceae by the Inuit and Yukon First Nations. Ledum decumbens (Aiton) Lodd. ex Steud Ericaceae is reported to be used in teas among the Cup-it Eskimo (Griffin 2001) and the Eskimo of the northern and Bering Sea regions of Alaska by Anderson (1939). Among the groups inhabiting the high Canadian Arctic, caribou stomach contents were considered the sole source of plant-based foods (Porsild 1953). Kuhnlein and Souieda (1992) also 
documented the use of caribou stomach contents as a traditional food in an Inuit community on Baffin Island. Among plants used as materials, Dritsas (1986) documented the use of Eriophorum scheuchzeri and E. angustifolium Roth Cyperaceae as wicks in the lamps of the Iglulingmiut. The Eskimo of the north Bering Sea and Arctic Alaska used Cassiope tetragona L. D. Don Ericaceae in concert with mosses and lichen as an insulating material, albeit for houses (Anderson 1939). The use of Arctostaphylos wva- ursi L. Ericacae as a substitute for or additive to tobacco is described in Porsild (1953). Many of these plants have retained their use in contemporary Kugluktuk culture, particularly those used for food and lamp wicks.

The traditional life of the Inuit differs in important respects from many other hunter-gatherer cultures. The relative abundance of large mammals of both the tundra and ocean supplied the primary staples of Inuit life. Food, clothing, shelter, and fuel could all be derived from animals. In spite of this bounty, plants were an important resource for the Kiluhikturmiut Inuinnait. The flora of the central Canadian Arctic provided the Kiluhikturmiut Inuinnait with increased dietary diversity in summer, with materials such as wicks and tinder that may have proven superior to animal-derived analogs, and with secondary metabolites for the treatment of disease.

\section{The Value of Traditional Kiluhikturmiut Inuinnait Knowledge}

The traditional plant-based knowledge of the Kiluhikturmiut Inuinnait holds both potential and realized value through contributions to nutrition and community health. The value of traditional Kiluhikturmiut Inuinnait knowledge is most apparent when considering the nutritional status of the population of Kugluktuk. The benefits of the traditional Inuit diet and decline in the nutritional value of food choices in response to availability of market foods have been highlighted by Kuhnlein and colleagues (2004). The harvesting and consumption of traditional foods continue to play a key role in the lifestyle of the Kiluhikturmiut Inuinnait, providing much needed access to fresh and unprocessed foods and improving the nutrient profile of the contemporary diet (Kuhnlein et al. 2004)

Knowledge of traditional plant-based medicine by healer Pauline Plamondon serves as an option for supplementary healthcare in a region where access to medicine can be limited. While medical services are available in the community, doctors visit only intermittently and patients must travel by air to access specialized treatment. Unlike the generalized knowledge of plants useful as food or materials, knowledge of medicinal plants was specialized. We argue that such specialized knowledge is a valuable component of local knowledge systems and deserves further consideration by ethnobiologists, anthropologists, community workers, and the medical profession.

\section{Specialized Knowledge versus Consensus}

Consensus analysis (sensu Reyes-Garcia et al. 2004) seeks to document shared cultural knowledge and makes the assumption that individuals that exhibit greater coherence of answers are considered most knowledgeable. Although, the idea of defining culture as that which is common to the group has great value in understanding cultural domains and normative experience (Boster 1986, Romney et al. 1986, ReyesGarcia et al. 2004), there are risks to this approach, particularly that specialized knowledge will be ignored or potentially labeled as "incorrect." Many cultures today are rapidly loosing ethnobotanical knowledge as indigenous languages are replaced by national and global languages (e.g. Dementi-Leonard and Gilmore 1999), habitat is destroyed, and a connection to the land is replaced by distant jobs and commercial goods. In such cases, preserving the remaining specialized ethnobotanical knowledge should be considered a priority.

Specialized knowledge is common in any organized system of relationships where certain activities are not easily observed by all members (Zelditch 1962). Specialization in knowledge is readily apparent in cultural subgroups where there is a division of labor and/or in cultural practices wherein a lack of specific knowledge can result in loss of life, for example, medicine, the art of boat-building, sailing, and warfare (Banack and Cox 1987; Boster and Johnson 1989; Cox 1991; Rondon and Banack 2003; Tongco 2007). One would expect a practitioner of a specialized art to have knowledge not broadly known. Any specialized knowledge that is used periodically would not necessarily be shared knowledge. However, it still may be valued by other members of a community and could be tightly linked to natural resources of the area. Likewise, knowledge that requires extensive apprenticeship is likely to reside in fewer individuals within a community and is of particular value to document when reliable individuals can be found.

In this study, we note that knowledge of plants gathered as food and used in material culture was 
generally held by most individuals. These are also the two areas where contemporary uses best align with historic accounts of Inuinnait culture. Medicinal knowledge, however, is not taught broadly to everyone, but is typically passed on only through apprenticeship to initiated individuals and its use is periodic, as in the Kiluhikturmiut Inuinnait. We regard this specialized knowledge as ethnographically important when held by individuals practicing the arts who are trusted by other community members. We encourage other ethnobiologists to record and report such specialized knowledge in addition to seeking out quantifiable data.

\section{Changes to Arctic Culture and Environment}

The rapid progression of Inuit cultural change is apparent in daily Inuinnait life. Commercial interests in arctic oil, diamonds, and natural gas suggest that the rate of change may continue to accelerate. Indeed, the Inuit now share a vested interest in resource extraction. Signed in 1993, the Nunavut Land Claims agreement provided the Inuit with the right to use and manage resources within the land claims area (Wenzel 2004). Employment opportunities in the resource extraction industry provide much needed employment, but also draw people away from traditional practices such as hunting and fishing and encourage further adoption of commercial foods. Kuhnlein and colleagues (2004) have noted the resultant changes in diet and nutritional status among the Canadian Inuit.

The biotic and abiotic environments of the Coronation Gulf region are likely to experience similar rapid change. Research suggests a change in the structure of ecological communities, a reduction of species diversity and evenness, and the replacement of $40 \%$ of the tundra with taiga by 2100 (Walker et al. 2006). Successful navigation of the Northwest Passage has become reality. Should conditions permit regular shipping routes through the Coronation Gulf region, the Kiluhikturmiut Inuinnait will find themselves on the shores of an international shipping lane instead of within the wilderness of today. A progressively changing climate thus threatens to alter not only local ecology but also to accelerate cultural change of the Inuinnait through increased exposure to external cultures and novel opportunities for employment.

The Territorial Government of Nunavut mandates the incorporation of Inuit traditional knowledge (qaujimajatuqangit) into governance and resource management (Wenzel 2004); however, few ethnobo- tanical accounts of the Inuit of Nunavut exist. The respect for knowledge or experience (qaujimanilik) is one of the principles of qaujimajatuqangit. The importance of traditional knowledge to Inuit culture and governance and the rate of acculturation of the Inuit indicate an urgency in documenting the knowledge and experience of the final generation that grew up with more traditional lifestyles. With Inuit communities dispersed from Siberia to Greenland, much remains to be documented. Though the Arctic flora represented a secondary resource to the Inuit the existing body of academic literature on Inuit ethnobotany suggests that plant-use among the Inuit deserves further consideration. Our work indicates the potential for a broader existence of an Inuit healing tradition that made use of the Arctic flora. We emphasize the need for efforts to identify and collaborate with individuals familiar with plant-based Inuit medicine.

\section{Acknowledgements}

We are indebted to all of the Kiluhikturmiut Inuinnait people of Kugluktuk who shared their knowledge and hospitality with us. Pauline Plamondon conveyed the teachings of her grandmother and the many generations of healers that preceded her. Peter Taptuna, head of the Kugluktuk Hunters and Trappers' Association, participated in this study and lent his support and guidance. Bob Appatok, Nellie Kanovak Hikok, Eric Kaiyogana, Fred Kaohina, Johnny Kaosoni, George Kavanna, and June Okalik Klengenberg, and the individuals who wish to remain anonymous, all shared their knowledge and time. The authors wish to thank Kathy Keeling, Levi Angutiqjuaq, Eugene and Almeda of Kugluktuk, George Atatahak, M. J. Katiak, Becky and Luigi Torretti, Alice Ayalik, Mathieu Dummond, Ken Taptuna, the Niptanatiak Family, the Kugluktuk Hunters and Trappers Association, Deputy Mayor of Kugluktuk, the Ilavut Center and Department of Biological Sciences and Associated Student Union at California State University, Fullerton.

\section{Declarations}

Permissions: Documentation of traditional knowledge was approved by the Nunavut Research Institute (License \# 0401306N-A). Informed consent was obtained from each participant. Interview methods were approved by California State University, Fullerton IRB. (Assurance \# FWA00000135). Collection of plant specimens was permitted under a 
wildlife research permit from the Nunavut Department of the Environment (Permit \#: WL 000872).

Sources of funding: Partial funding was provided by a Natural Science and Mathematics Research Award granted to Banack.

Conflicts of interest. None declared.

\section{References Cited}

Anderson, J. P. 1939. Plants used by the Eskimo of the northern Bering Sea and arctic regions of Alaska. American Journal of Botany 26:714-716.

Banack, S.A. and P. A. Cox. 1987. Ethnobotany of Ocean-Going Canoes in Lau, Fiji. Economic Botany 41:148-162.

Bliss, L. C. 1971. Arctic and Alpine Plant Life Cycles. Annual Review of Ecology and Systematics 2:405-438.

Boster, J. S. 1986. Exchange of Varieties and Information between Aguaruna Manioc Cultivators. American Anthropologist 88:428-436.

Boster, J. S. and J. C. Johnson. 1989. A Comparison of Expert and Novice Judgments of Similarity among Fish. American Anthropologist 91:866-889.

Condon, R. G. 1996. The Northern Copper Inuit: a History. University of Oklahoma Press, Norman, $\mathrm{OK}$.

Cox, P. A. 1991. Polynesian Herbal Medicine. In Islands, Plants, and Polynesians, edited by P. A. Cox and S. A. Banack, pp. 147-169. Dioscorides Press, Portland, OR.

Dementi-Leonard, B. and P. Gilmore. 1999. Language Revitalization and Identity in Social Context: A Community-Based Athabascan Language Preservation Project in Western Interior Alaska. Anthropology \& Education Quarterly 30:37-55.

Dritsas, P. 1986. Plants in Inuit culture: The Ethnobotany of the Iglulingmiut. Master's Thesis, Université Laval, Ville de Québec, Canada.

Griffin, D. 2001. Contributions to the Ethnobiology of the Cup'it Eskimo, Nunivak Island, Alaska. Journal of Ethnobiology 21:91-127.

Helgason, A., G. Pálsson, H. S. Pedersen, E. Angulalik, E. D. Gunnarsdóttir, B. Yngvadóttir and K. Stefánsson. 2006. mtDNA variation in
Inuit Populations of Greenland and Canada: Migration History and Population Structure. American Journal of Physical Anthropology 130:123-134.

Jenness, D. 1916. Anthropological Notes. American Anthropologist 18:612-620.

Kuhnlein, H. V. and R. Soueida. 1992. Use and Nutrient Composition of Traditional Baffin Island Foods. Journal of Food Composition and Analysis 5:112126.

Kuhnlein, H. V., H. M. Chan, D. Leggee and V. Barthet. 2002. Macronutrient, Mineral and Fatty Acid Composition of Canadian Arctic Traditional Food. Journal of Food Composition and Analysis 15:545566.

Kuhnlein, H. V., O. Receveur, R. Soueida and G. M. Egeland. 2004. Arctic Indigenous Peoples Experience the Nutrition Transition with Changing Dietary Patterns and Obesity. Journal of Nutrition 124:1447-1453.

Porsild, A. E. 1953. Edible Plants of the Arctic. Arctic 6:15-34.

Porsild, A. E. and W. J. Cody. 1980. Vascular Plants of Continental Northwest Territories, Canada. National Museum of Natural Sciences, Ottawa.

Reyes-Garcia, V., E. Byron, V. Vadez, R. Godoy, L. Apaza, E. P. Limache, W. R. Leonard and D. Wilkie. 2004. Measuring Culture as Shared Knowledge: Do Data Collection Formats Matter? Cultural Knowledge of Plant Uses Among Tsimane' Amerindians, Bolivia. Field Methods 16:135-156.

Romney, A. K., S. C. Weller and W. H. Batchelder. 1986. A Theory of Culture and Informant Accuracy. American Anthropologist 88:313-338.

Rondon, X. J., S. A. Banack and W. DiazHuamanchumo. 2003. Ethnobotanical Investigation of Caballitos (Schoenoplectus californicus: Cyperaceae) in Huanchaco, Peru. Economic Botany 57:35-47.

Spradley, J. P. 1979. The Ethnographic Interview. Holt, Rinehart and Winston. New York.

Stefánsson, V. 1913. My Life with the Eskimo. Macmillan Company, New York.

Tongco, Ma. D. C. 2007. Purposive Sampling as a Tool for Informant Selection. Ethnobotany Research and Applications 5:147-158.

Usher, P. J. 1965. Economic Basis and Resource Use of the 
Coppermine-Holman Region. Department of Northern Affairs and National Resources, Ottawa.

Walker, M. D., C. H. Wahren, R. D. Hollister, G. H. R. Henry, L. E. Ahlquist, J. M. Alatalo, M. S. BretHarte, M. P. Calef, T. V. Callaghan, A. B. Carroll, H. E. Epstein, I. S. Jónsdóttir, J. A. Klein, B. Magnússon, U. Molau, S. F. Oberbauer, S. P. Rewa, C. H. Robinson, G. R. Shaver, K. N. Suding, C. C. Thompson, A. Tolvanen, $\varnothing$. Totland, P. L. Turner, C. E. Tweedie, P. J. Webber and P. A. Wookey. $2006 . \quad$ Plant Community Responses to Experimental Warming Across the Tundra Biome. Proceedings of the National Academy of Sciences 103:1342-1346.
Wenzel, G. 2004. From TEK to IQ: Inuit Qaujimajatuqangit and Inuit Cultural Ecology. Arctic Anthropology 41:238-250.

Zelditch, M. 1962. Some Methodological Problems of Field Studies. American Journal of Sociology 67:566576.

\section{Biosketch}

Jonathan Duffy Davis is a biologist at Fullerton Arboretum, a botanical garden on the campus of California State University-Fullerton.

Sandra Banack is the senior scientist at the Institute for Ethnomedicine, Jackson, WY. 
Appendix 1: Photos

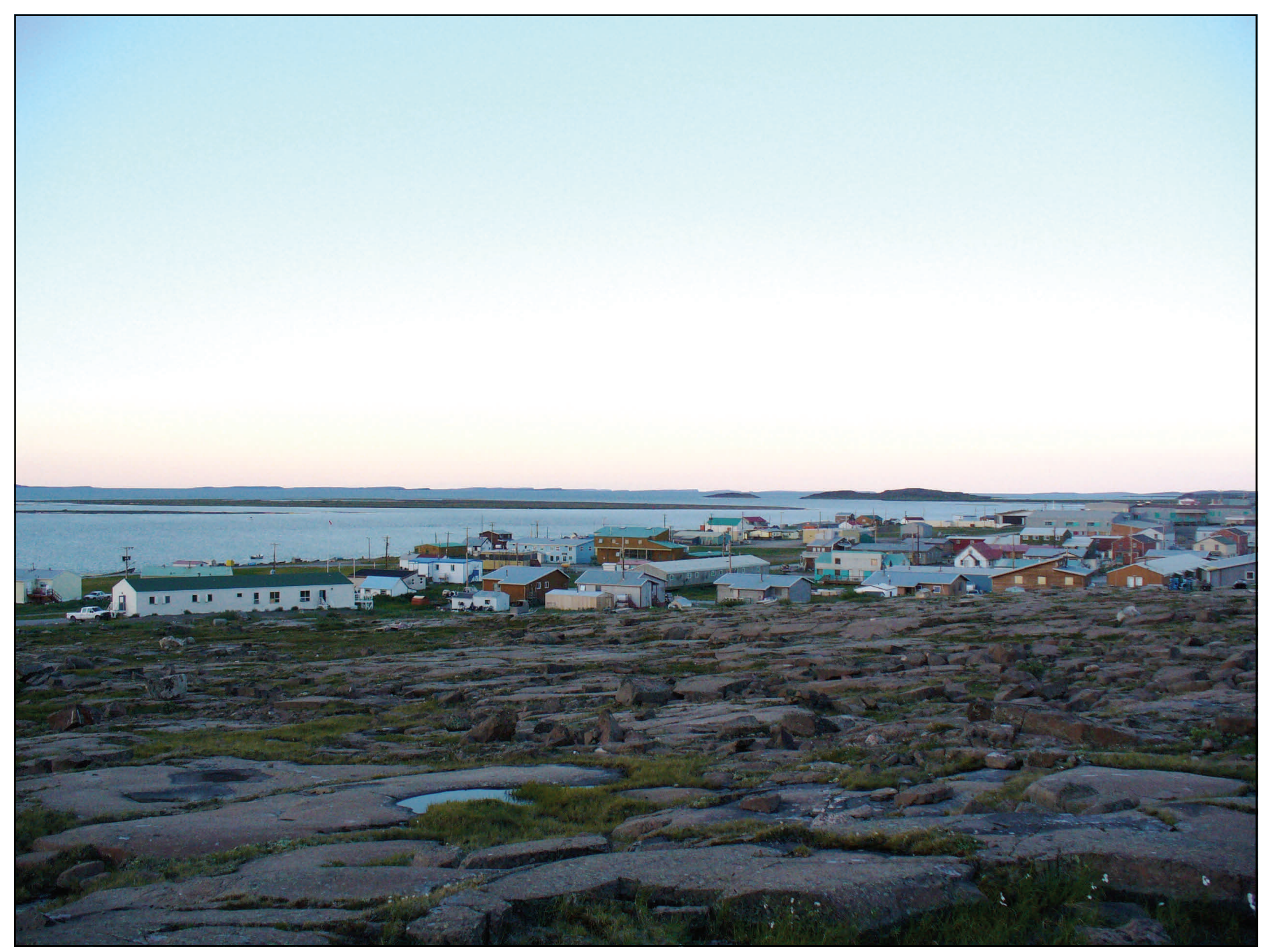

Photo 1. Kugluktuk is a small hamlet located on the shores of the Coronation Gulf in the central Canadian Arctic. 


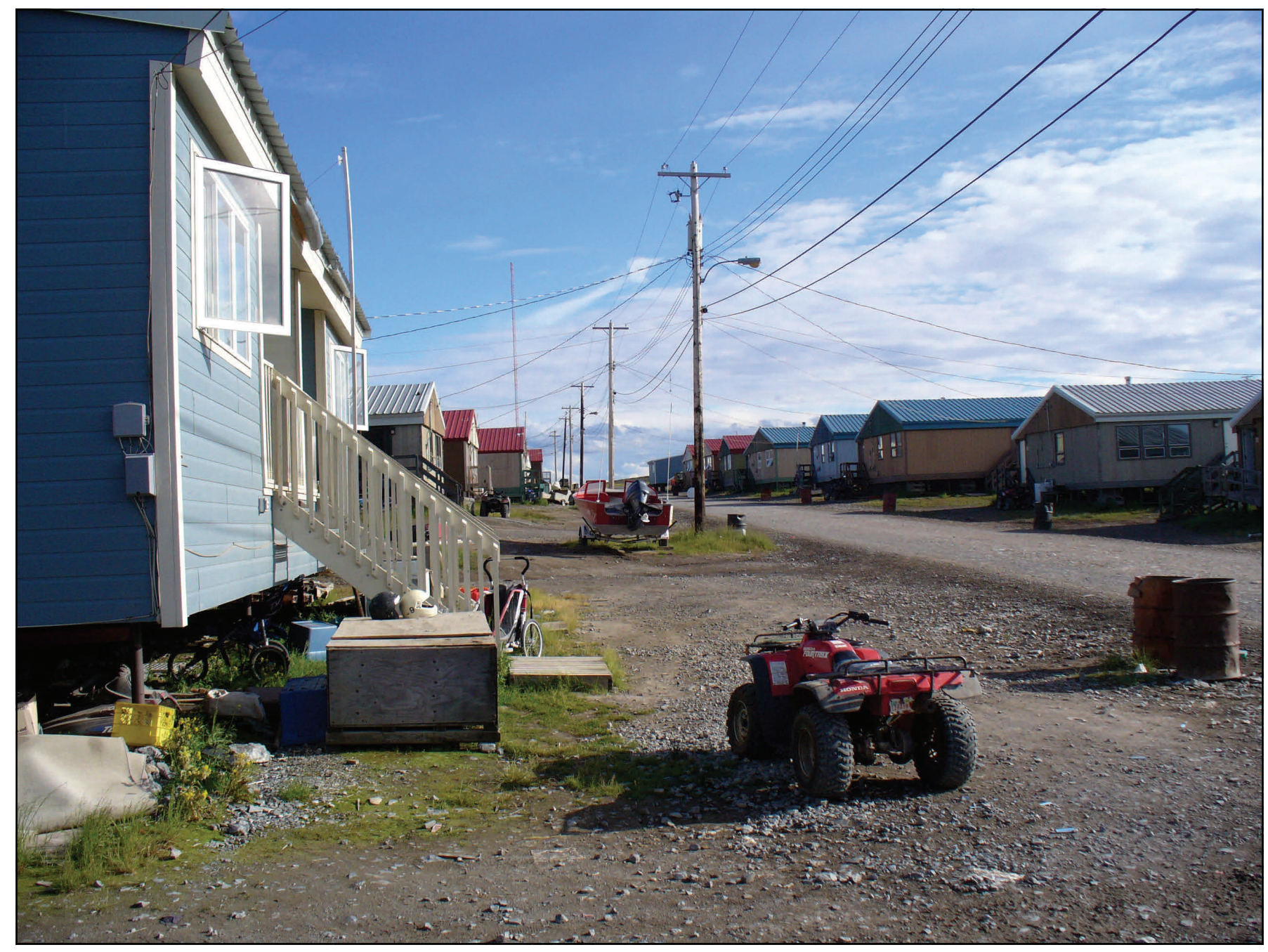

Photo 2. The contemporary Kiluhikturmiut Inuinnait live in modular homes that line the streets of Kugluktuk. 
Et Ethnobiology Letters research Communication

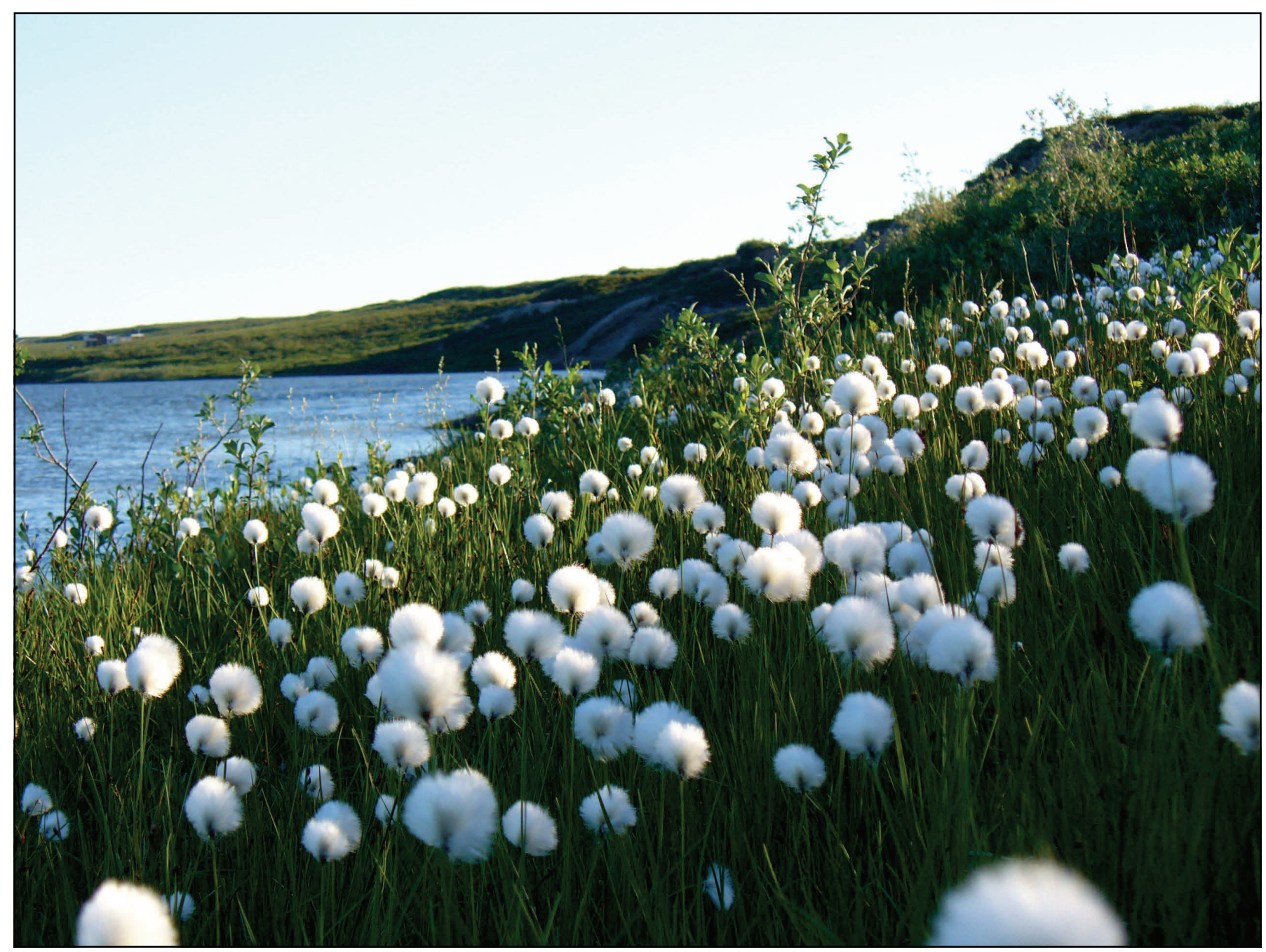

Photo 3. The bristles of Eriophorum scheuchzeri Hoppe Cyperaceae were traditionally gathered and used as a wick in seal-oil lamps (qulliq). 
(f) EThNobiolocy Letters Research Communication

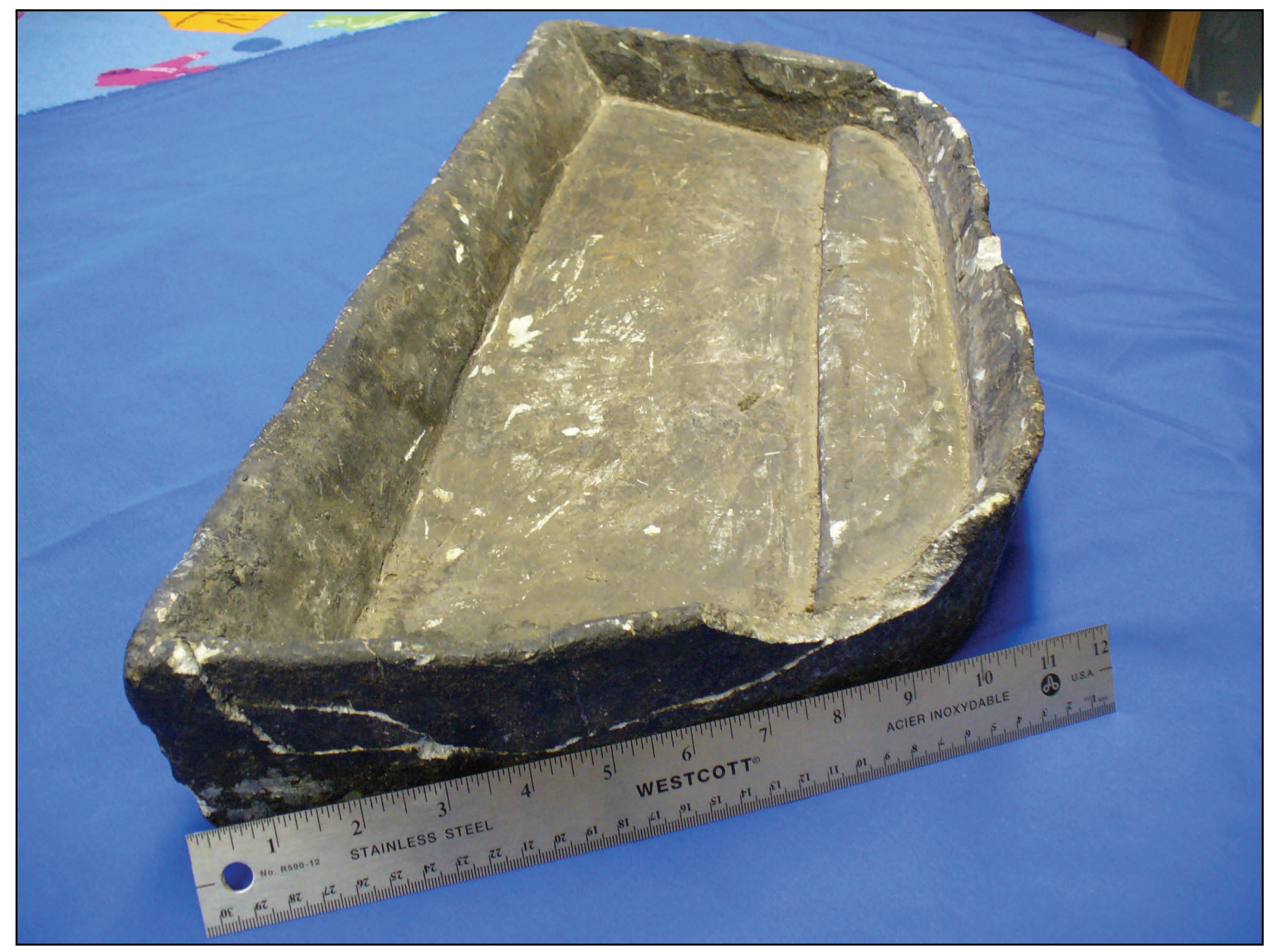

Photo 4. A qulliq was usually constructed from soapstone. The wick material would be placed along the upper ledge of the lamp and the lower reservoir filled with rendered fat. 